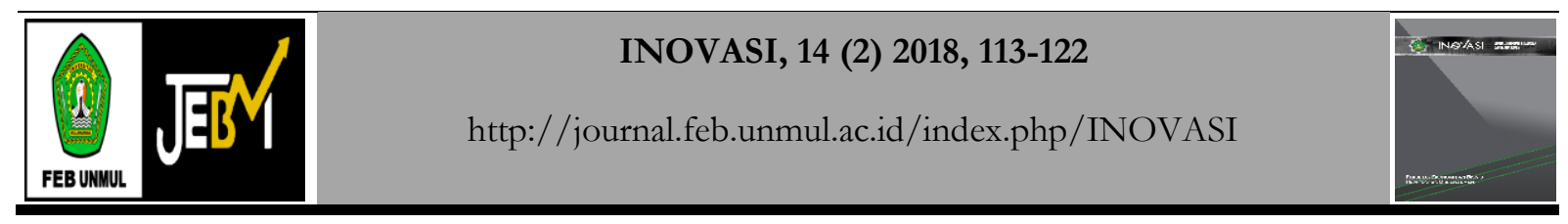

\title{
Peran sosialisasi dan edukasi dalam menumbuhkan minat investasi di pasar modal syariah
}

\author{
Ferry Khusnul Mubarok \\ Fakultas Ekonomi dan Bisnis Islam UIN Walisongo, Semarang. \\ Email: ferrykhusnulmubarok@walisongo.ac.id
}

\begin{abstract}
Abstrak
Penelitian ini bertujuan untuk mengidentifikasi berbagai jenis sosialisasi dan edukasi, dan peranannya terhadap minat investasi, mengidentifikasi faktor pendukung dan penghambat, serta menganalisis efektivitas sosialisasi dan edukasi pasar modal syariah. Penelitian ini menggunakan pendektan kuantitatif deskriptif. Sumber data yang digunakan merupakan data primer yang diperoleh dari penyebaran kuesioner. Hasil penelitian menunjukkan bahwa sosialisasi dan edukasi kepada mahasiswa melibatkan berbagai informan yang meliputi teman, dosen, pengurus galeri investasi, seminar, kuliyah, media (cetak maupun elektronik), selebaran, guru SMA, buku, orang tua, dan internet. Sosialisasi dan edukasi juga melibatkan media sosial yang meliputi facebook, BBM, line, blog, whatsap, instagram, kakaotalk, buku, twitter, internet (searching), dan wechat. Peran masing-masing informan dan media beragam, baik dari sisi intensitas maupun pengaruhnya (peranan) terhadap minat investasi mahasiswa. Faktor pendukung minat investasi mahasiswa meliputi memajukan pasar modal, keingintahuan, untuk tabungan masa depan, ingin mendapatkan keuntungan (laba),belum tahu, ingin menjadi pengusaha sukses, ingin kaya, ingin berinvestasi, ingin memiliki saham, karena menjanjikan, dan warren buffet (tokoh). Sementara faktor pengahambatnya meliputi modal (uang), kerugian, kurangnya pengetahuan (cara dan tempat), ragu-ragu kesyariahannya. Berdasarkan temuan tersebut, maka perlu adanya strategi untuk mengoptimalkan peranan sosialisasi dan edukasi agar semakin luas dan merata.
\end{abstract}

Kata Kunci: Sosialisasi; edukasi; investasi; dan pasar modal syariah

\section{The role of socialization and education in growing interest in investment in the sharia capital market}

\begin{abstract}
This study aims to identify various types of socialization and education, and their role in investment interests, identify supporting and inhibiting factors, and analyze the effectiveness of sharia capital market socialization and education. This study uses descriptive quantitative approach. The source of data used is primary data obtained from questionnaires. The results showed that the socialization and education of students involved various informants including friends, lecturers, investment gallery administrators, seminars, lecturers, media (print and electronic), leaflets, high school teachers, books, parents, and the internet. Socialization and education also involve social media which includes Facebook, BBM, line, blog, whatsap, instagram, kakaotalk, books, twitter, internet (searching), and wechat. The role of each informant and the media is diverse, both in terms of intensity and influence (role) on student investment interests. Supporting factors of student investment interests include advancing capital markets, curiosity, for future savings, wanting to get profits (profits), not knowing, wanting to be a successful entrepreneur, wanting to be rich, wanting to invest, wanting to own shares, because of promises, and warren buffets (figures). While the inhibiting factors include capital (money), loss, lack of knowledge (way and place), doubtfulness of the society. Based on these findings, it is necessary to have a strategy to optimize the role of socialization and education to be more widespread and equitable.
\end{abstract}

Keywords: Socialization; education; investment; and islamic capital market 


\section{PENDAHULUAN}

Perkembangan pasar modal syariah, salah satunya didukung oleh peranan berbagai pihak terutama dalam melakukan sosialisasi dan edukasi (Gunawan, 2011). Sosialisasi dan edukasi dilakukan untuk masyarakat, baik institusi maupun perorangan, dunia pendidikan, dan sosialisasi secara nasional maupun internasional (OJK, 2015). Sosialisasi dan edukasi di ksmpus telah dilakukan, baik secara langsung maupun tidak langsung. Sosialisasi dan edukasi di lingkungan kampus secara langsung, meliputi: seminar, workshop, pelatihan, simulasi dan kompetisi baik tingkat regional maupun nasional, bahkan sampai tingkat internasional. Sementara, sosialisasi dan edukasi yang tidak langsung yaitu dengan cara memanfaatkan media, baik media elektronik, media cetak maupun media online. Di samping menggunakan model tersebut, untuk meningkatkan pengetahuan mahasiswa tehadap pasar modal syariah dilakukan dengan cara menawarkan mata kuliah pasar modal syariah, maupun mata kuliah yang berkaitan dengan investasi yang didalamnya dibahas materi tersebut. Di samping itu, untuk semakin memperluas pemahaman mahasiswa beberapa universitas yang bekerja sama dengan PT Bursa Efek Indonesia. Bentuk kerjasama tersebut yaitu dengan terdapatnya galeri investasi. Adanya galeri investasi ini bertujuan untuk memberikan fasiltas kepada mahasiswa untuk dapat mengakses segala informasi tentang pasar modal syariah. Bahkan mahasiswa juga dapat mengakses praktik langsung melalui simulasi trading. Dukungan dari para perusahaan sekuritas pun juga dilakukan, terutama dalam memberikan akses kemudahan bagi para mahasiswa untuk mulai membuka rekening dan memulai trading, yaitu hanya dengan Rp. 100.000,00 sudah dapat melakukan transaksi.

Tujuan sosialisasi dan edukasi, salah satunya adalah untuk meningkatkan jumlah investor di pasar modal (www.ksei.co.id). Di samping itu juga untuk meningkatkan kepercayaan investor terhadap pasar modal syariah (Yanti, Ubud, Made, \& Djumahir, 2012). Berbagai dukungan tersebut pada faktanya belum menemui hasil yang diharapkan. Hasil Survei Nasional Literasi Keuangan dalam Roadmap Pasar Modal Syariah (2015-2019), mayoritas masyarakat Indonesia (lebih dari 90\%) masih belum mengenal pasar modal. Penggunaan instrumen pasar modal masih sedikit, yakni hanya kurang dari $1 \%$. Jika dibandingkan dengan negara-negara Asia lainnya, Indonesia seharusnya memiliki potensi yang lebih besar dalam meningkatkan jumlah investor pada efek-efek syariah di pasar modal. Namun demikian, jumlah investor di pasar modal masih sangat rendah, yaitu 0,33 juta $(0,14 \%)$ dibanding negara-negara Asia lainnya (Tim Kajian Minat Investor Terhadap Efek Syariah di Pasar Modal: 2011).

Dengan demikian, pada dasarnya minat masyarakat Indonesia dalam berinvestasi masih terbilang rendah, terutama investasi di pasar modal syariah. Idealnya Indonesia memiliki potensi yang tinggi dalam hal jumlah investor syariah, karena mayoritas penduduk Indonesia adalah muslim. Hal ini disebabkan karena kurangnya pemahaman masyarakat tentang pasar modal syariah, dan juga kurangnya sosialisasi dan kepada masyarakat tentang pasar modal syariah (Supriadi \& Hariyanto, 2017). Hal ini dipertegas dalam penelitian Khotimah, Warsini, \& Nuraeni (2016) yang mengaskan bahwa sosialisasi dan pengetahuan berpengaruh terhadap minat investasi di pasar modal pada efek syariah. Hasil penelitian Peristiwo (2016) menunjukkan bahwa rendahnya minat investasi disebabkan karena kurangnya edukasi dan sosialisasi terutama berkaitan dengan efek syariah. Dengan demikian, penelitian bertujuan untuk mengidentifikasi peran sosialisasi dan edukasi terhadap minat investasi di pasar modal syariah. Secara khusus penelitian ini bertujuan untuk mengidentifikasi berbagai sosialisasi dan edukasi yang sudah dilakukan, mengidentifikasi peranan media sosialiasai terhadap minat investasi, mengidentifikasi faktor pendukung dan penghambat, serta menganalisis efektivitas sosialisasi dan edukasi pasar modal syariah.

\section{METODE}

Penelitian ini merupakan jenis penelitian lapangan (field research). Kajian dalam riset ini menggunakan dua macam kajian, yaitu kajian deskriptif dan analisis konstruktif. Kajian deskriptif dilakukan dengan cara mengidentifikasi berbagai temuan, yang kemudian berdasarkan temuan tersebut disajikan secara terstruktur dan sistematis. Dalam hal ini adalah mengidentifikasi berbagai sosialisasi dan edukasi yang sudah dilaksanakan. Dalam penelitian ini juga mengkaji secara analitif konstruktif, yaitu dengan berbekal berbagai temuan yang ada dalam berbagai sosialisasi dan edukasi tersebut, yang kemudian diidentifikasi berbagai hal mulai dari efektivitas dan pengaruhnya terhadap minat investasi mahasiswa. 
Penelitian ini menggunakan dua sumber data, yaitu data primer dan sekunder Data primer merupakan data yang diperoleh secara langsung dari lapangan, tanpa melalui pihak ke tiga (Bungin, 2010). Dalam hal ini berupa data yang diperoleh melalui penyebaran kuesioner. melalui penyebaran angket (kuesioner). Sementara itu, data sekunder merupakan data yang diperoleh melaui pihak ketiga yang berupa hasil riset terdahulu yang memiliki keterkaitan, dan sumber-sumber lain berupa data dari website yang berkaitan serta dapat memberikan informasi yang dibutuhkan.

Sumber data dalam penelitian ini yang berupa primer merupakan data yang diperoleh melalui penyebaran kuesioner. Kuesioner disebar kepada para mahasiswa dari berbagai universitas yang ada di Semarang. Dalam penelitian menggunakan sampel dengan populasi yaitu seluruh mahasiswa yang berasal dari berbagai universitas yang di Semarang. Pengambilan sampel menggunakan pendekatan non probability sampling, yang mana setiap anggota populasi memiliki peluang yang sama untuk menjadi sampel (Idrus, 2009). Sementara itu teknik pengambilan data menggunakan metode purposive sampling, yaitu teknik pengambilan sampel dengan cara menentukan berdasarkan kriteria untuk dijadikan sampel. Kriteria sampelnya adalah sebagai berikut:

Mahasiswa berada di Universitas sekitar Semarang dan tergabung dalam Fakultas Ekonomi dan Bisnis (FEB) jika Universitas umum, atau di Fakultas Ekonomi dan Bisnis Islam (FEBI) jika Universitas Islam. Universitas ataupun Fakultas tersebut memiliki galeri investasi.

Di Universitas tersebut juga terdapat kelompok studi pasar modal atau semacamnya.

Kriteria tersebut bertujuan untuk mengukur seberapa besar peranan sosialisasi dan edukasi di universitas yang notabenya adalah lebih dekat dengan bidangnya, yang mana pasar modal bukan hal yang asing dilingkungan universitas tersebut. Setelah dilakukan observasi dibeberapa Universitas di Semarang diperoleh empat Universitas yang memenuhi kriteria tersebut, antara lain Universitas Islam Negeri Walisongo Semarang, Universitas Diponegoro Semarang, Universitas Negeri Semarang, dan Universitas Dian Nuswantoro Semarang.

Metode analisis dan penyajian data menggunakan pendekatan kuantitatif deskriptif. Penyajian data dalam penelitian ini yaitu dengan mengidentifikasi dan mendeskripsikan berbagai temuan lapangan tentang sosialisasi dan edukasi pasar modal syariah, yang meliputi:

Mengidentifikasi dan mendeskripsikan berbagai informan yang terlibat dalam sosialisasi dan edukasi pasar modal syariah.

Mengidentifikasi dan mendeskripsikan berbagai media yang digunakan untuk sosialisasi dan edukasi pasar modal syariah.

Mengidentifikasi peranan sosialisasi dan edukasi dalam mempengaruhi minat investasi mahasiswa di pasar modal syariah.

Mendeskripsikan dan mengidentifikasi berbagai faktor pendukung dan penghambat dalam sosialisasi dan edukasi terutama peranannya terhadap minat investasi di pasar modal syariah.

Mengidentifikasi dan menganalisis efektivitas sosialisasi dan edukasi pasar modal syariah dalam membangun minat investasi mahasiswa di pasar modal syariah.

\section{HASIL DAN PEMBAHASAN}

\section{Temuan Lapangan tentang Sosialisasi dan Edukasi Pasar Modal Syariah}

Berdasarkan hasil dari penyebaran kuesioner tentang sosialisasi dan edukasi di lingkungan kampus yaitu sebanyak 250 kuesioner, namun hanya terkumpul sebanyak 178 kuesioner yang dapat dijadikan bahan analisis. Kuesioner disebar di empat Universitas di semarang, yaitu Universitas Islam Negeri Walisongo Semarang, Universitas Diponegoro Semarang, Universitas Dian Nuswantara Semarang, dan Universitas Negeri Semarang. Universitas-universitas tersebut memiliki galeri investasi dan memiliki kelompok studi pasar modal dengan nama-nama yang beragam, di UIN walisongo nama organisasinya adalah Kelompok Studi Pasar Modal (KSPM) Walisongo, di UNDIP adalah KSPM UNDIP, di UDINUS adalah KSPM UDINUS, dan di UNNES adalah UNSAF. Data tersebut menunjukan bahwa $83 \%$ responden mengetahui Pasar Modal Syariah, dan sisanya adalah tidak tahu sebesar $17 \%$. Para responden mengetahui Pasar Modal Syariah, yaitu melalui berbagai informan yang ikut berperan dalam memberikan informasi tentang pasar modal syariah. Informan tersebut dapat di lihat dalam gambar 1. 


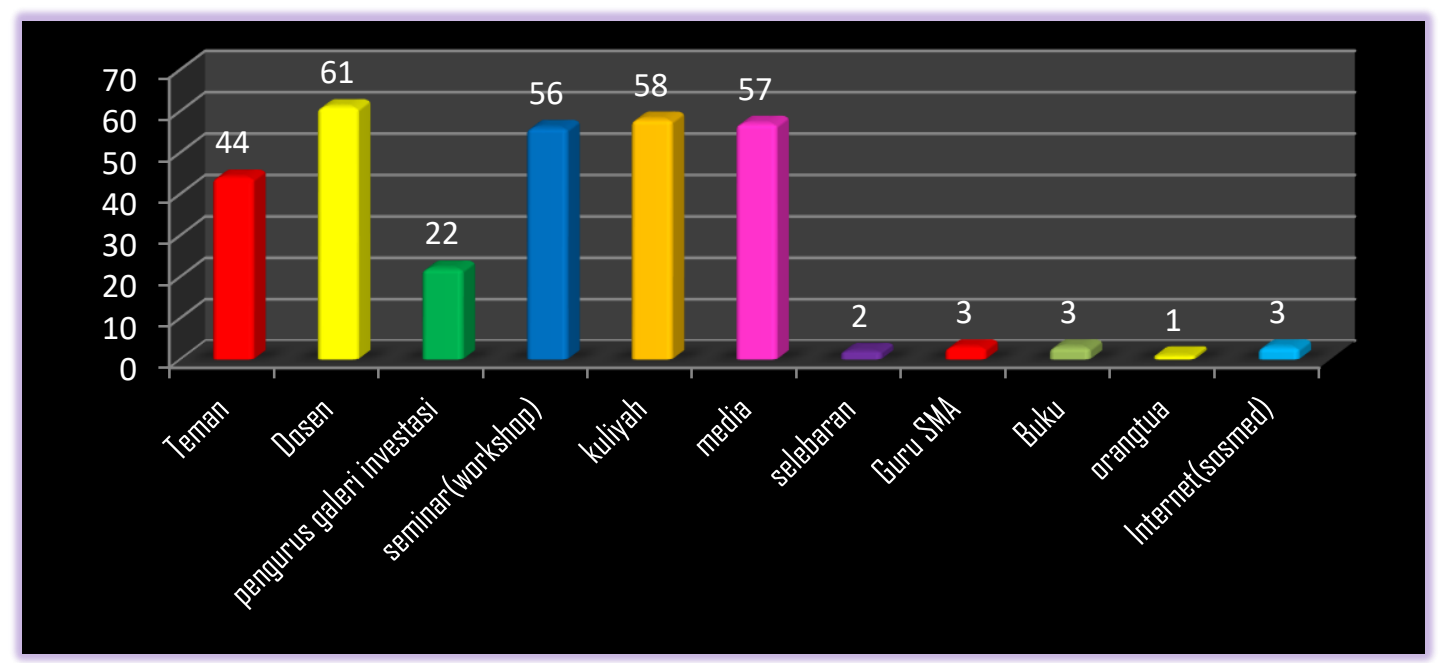

Gambar 1. Berbagai Informan Pasar Modal Syariah

Sumber: Data primer yang diolah

Berdasarkan gambar di atas, para responden mendapatkan informasi tentang pasar modal syariah melalui sebelas informan. Informan tersebut meliputi teman, dosen, pengurus galeri investasi, seminar, kuliyah, media (cetak maupun elektronik), selebaran, guru SMA, buku, orang tua, dan internet. Dalam hal ini satu responden dapat memperoleh informasi dari beberapa informan (tidak hanya satu informan). Informan tertinggi yang dapat memberikan informasi tersebut adalah Dosen. Pada temuan kedua tentang sosialisasi dan edukasi pasar modal syariah tidak lepas dari peranan media sosial (sosmed). Peranan sosmed dalam menginformasikan atau mensosialisasikan kepada para responden tentang pasar modal syariah terdapat dalam gambar 2.

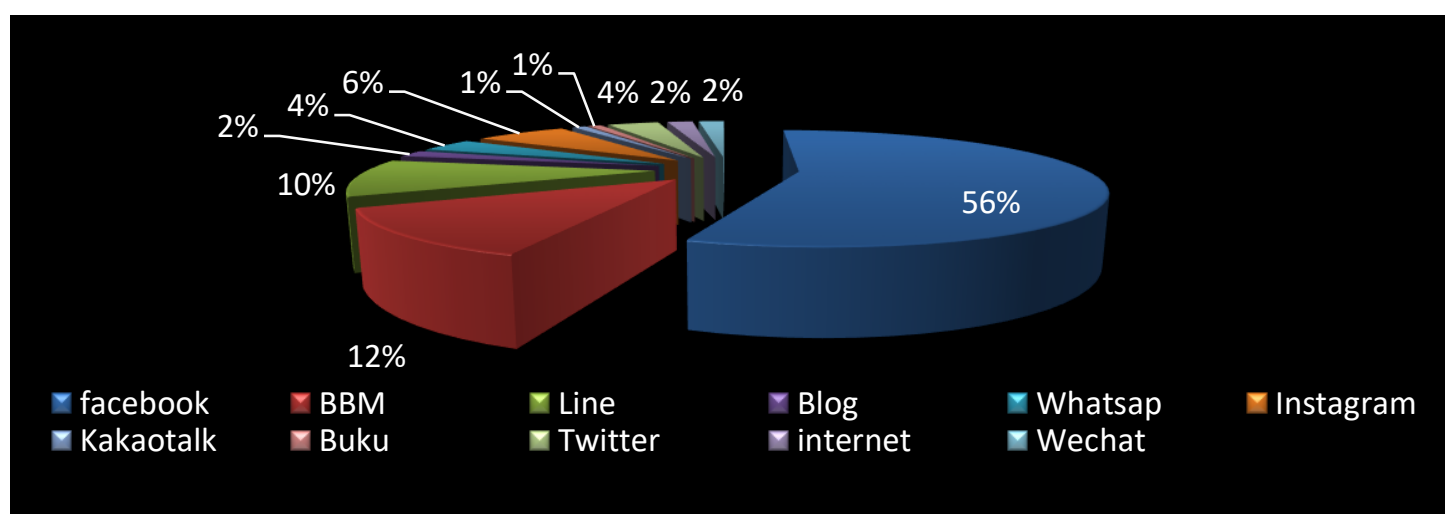

Gambar 2. Berbagai Media Sosialisasi Pasar Modal Syariah

Sumber : Data primer yang diolah

\section{Peranan Sosialisasi dan Edukasi dalam Membangun Minat Investasi}

Berdasarkan data, peran masing-masing media sosialisasi dan edukasi cukup beragam dan masingmasing juga memiliki pengaruh yang berbeda-beda terhadap minat para mahasiswa untuk berinvestasi di pasar modal syariah. Peran media sosialisasi menurut responden, antara lain melalui workshop atau seminar maupun pelatihan, media perkuliahan, buku, media cetak, media elektronik, media social, media internet, galeri investasi, dan PIPM (Pusat Informasi Pasar Modal). Berdasarkan data menunjukkan bahwa yang paling berperan cukup besar sebagai media sosialisasi dan edukasi adalah melalui media internet, sedangkan yang paling kecil kontribusinya adalah PIPM. PIPM cukup rendah kontribusinya, karena dari beberapa responden belum mengenal apa yang dimaksud dengan PIPM. 


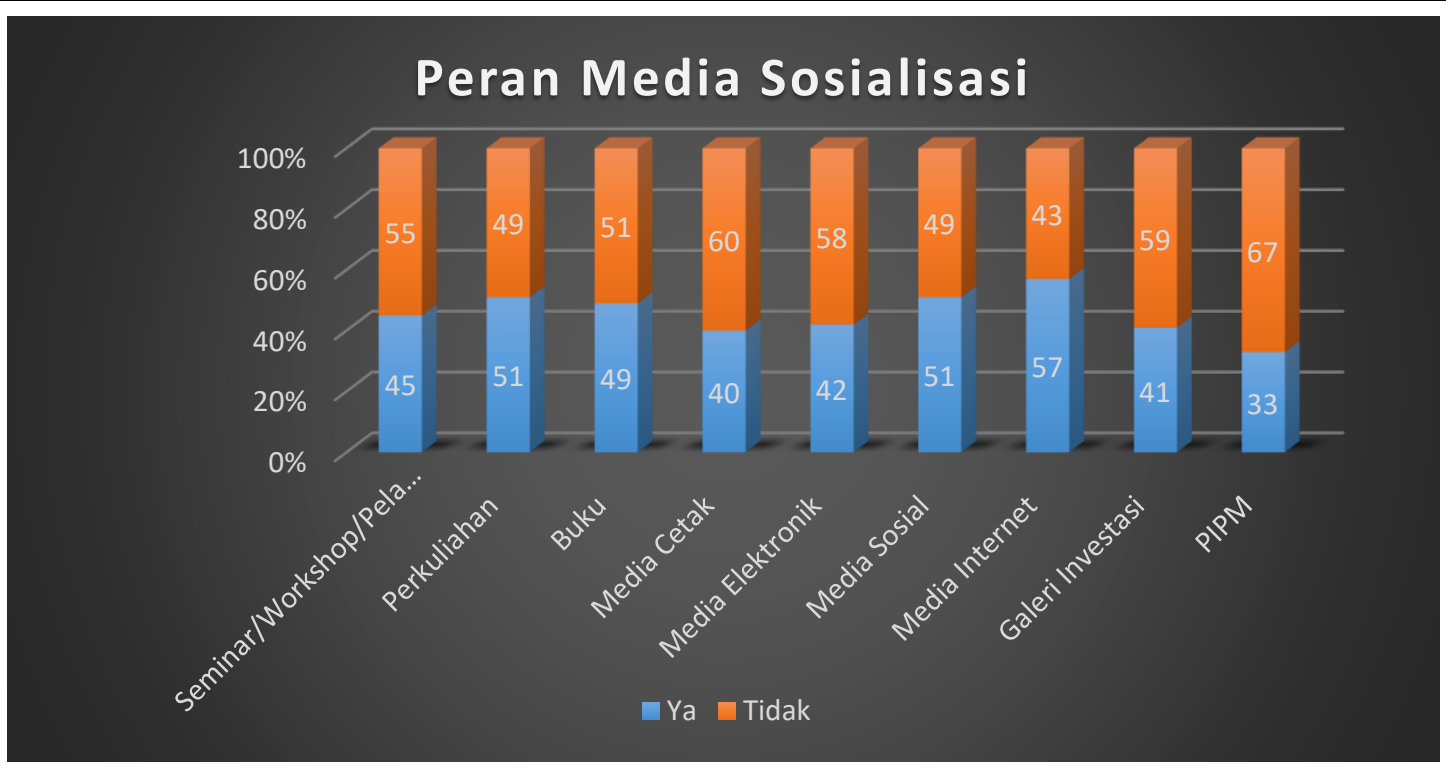

Gambar 3. Peran Media Sosialisasi Pasar Modal Syariah

Sumber: Data primer yang diolah

Media sosialisasi dan edukasi tersebut, disamping memliki peran untuk memberikan informasi kepada para calon investor, ternyata juga memiliki dampak atau pengaruh kepada para mahasiswa untuk berinvestasi di pasar modal syariah. Masing-masing memiliki perngaruh yang berbeda, sebagaimana tampak dalam gambar 4.

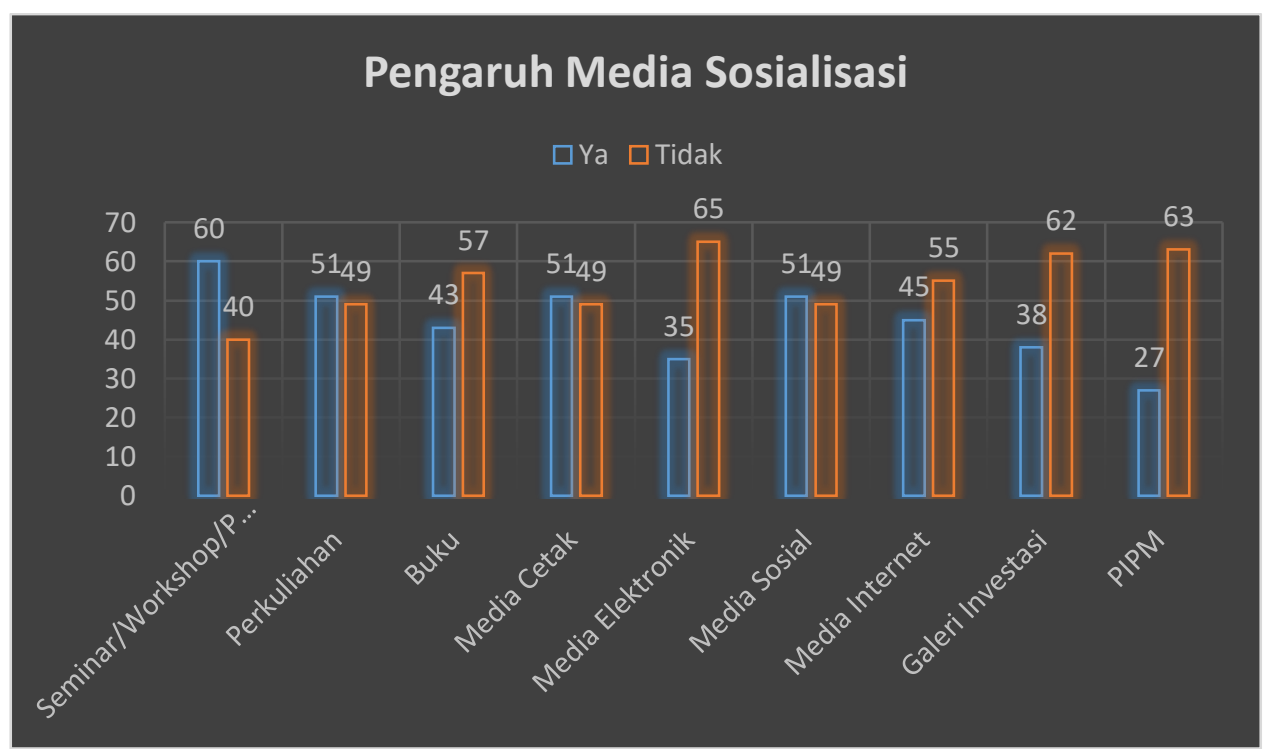

Gambar 4. Peran Media Sosialisasi Pasar Modal Syariah

Sumber: Data primer yang diolah

\section{Faktor-faktor yang Menghambat dan Mendukung Minat Investasi}

Untuk membangun minat investasi mahasiswa memang diperlukan pendekatan khusus, salah satunya melalui sosialisasi dan edukasi yang mampu menarik perhatian mereka. Secara umum sebagian besar responden pada dasarnya berminat untuk investasi. Hal ini ditunjukan sebanyak $73 \%$ responden menjawab berminat untuk berinvestasi di pasar modal syariah, dan hanya $27 \%$ responden yang menjawab tidak berminat. Salah satu alasan para responden berminat investasi adalah adanya pengetahuan para responden tentang pasar modal syariah. Gambar di bawah ini menunjukan pengetahuan mahasiswa tentang pasar modal syariah. 


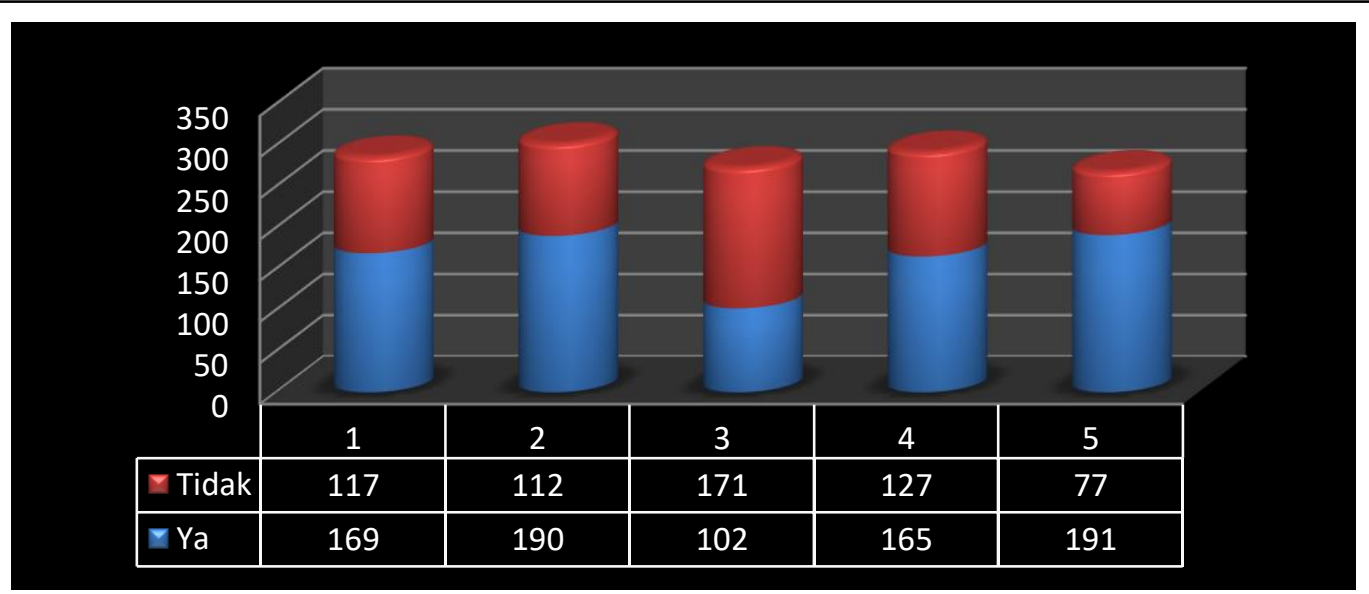

Gambar 5. Pengetahuan Responden Tentang Pasar Modal Syariah

Sumber: Data primer yang diolah

Berdasarkan data yang diperoleh bahwa sebagian dari responden sudah mengetahui perbedaan antara pasar modal konvensional dan syariah, yaitu ditunjukkan pada diagram batang dengan kode 1 yang mana sebesar $52 \%$ responden sudah mengetahui perbedaan. Sementara itu sisanya $48 \%$ responden belum bisa membedakan keduannya. Para responden juga sudah mulai mengetahui berbagai instrumen di pasar modal syariah, yang mana ditunjukan dengan diagram batang kode 2 yang menunjukkan bahwa $57 \%$ responden menjawab demikian. Sementara itu sisanya $43 \%$ responden belum mengetahui berbagai instrumen yang ada di pasar modal syariah. Temuan berikutnya adalah pengetahuan mengenai indeks yang tergabung dalam indeks syariah, yang mana ditunjukkan oleh diagram batang kode 3. Pada gambar tersebut menunjukkan bahwa pengetahuan tentang indeks tersebut masih sangat rendah yaitu hanya ada $25 \%$ responden, sementara $75 \%$ belum mengetahuinya.

Temuan lain adalah tentang pengetahuan berbagai sektor di pasar modal syariah, dalam hal ini ditunjukkan oleh diagram batang kode 4 , yang mana hanya ada $47 \%$ responden yang mengetahui berbagai sektor yang ada dalam pasar modal syariah. Sementara itu, sisanya 53\% belum mengetahuinya. Temuan berikutnya adalah mengenai pengetahuan responden tentang risiko yang akan dihadapi ketika berinvestasi di pasar modal syariah. Dalam hal ini ditunjukkan oleh diagram batang dengan kode 5, yang menunjukkan bahwa responden yang sudah mengetahui informasi tersebut adalah sebanyak $64 \%$. Sementara itu sisanya 36\% responden belum mengetahui berbagai risiko yang dihadapi ketika berinvestasi di pasar modal syariah. Dengan pengetahuan yang sudah berkembang, para responden pada dasarnya berminat untuk investasi. Hal ini terutama dilihat dari motivasi responden dalam rangka investasi di pasar modal syariah, yang dapat dikategorikan sebagai faktor yang mendukung para responden untuk investasi di pasar modal. Faktor-faktor tersebut nampak di dalam gambar berikut.

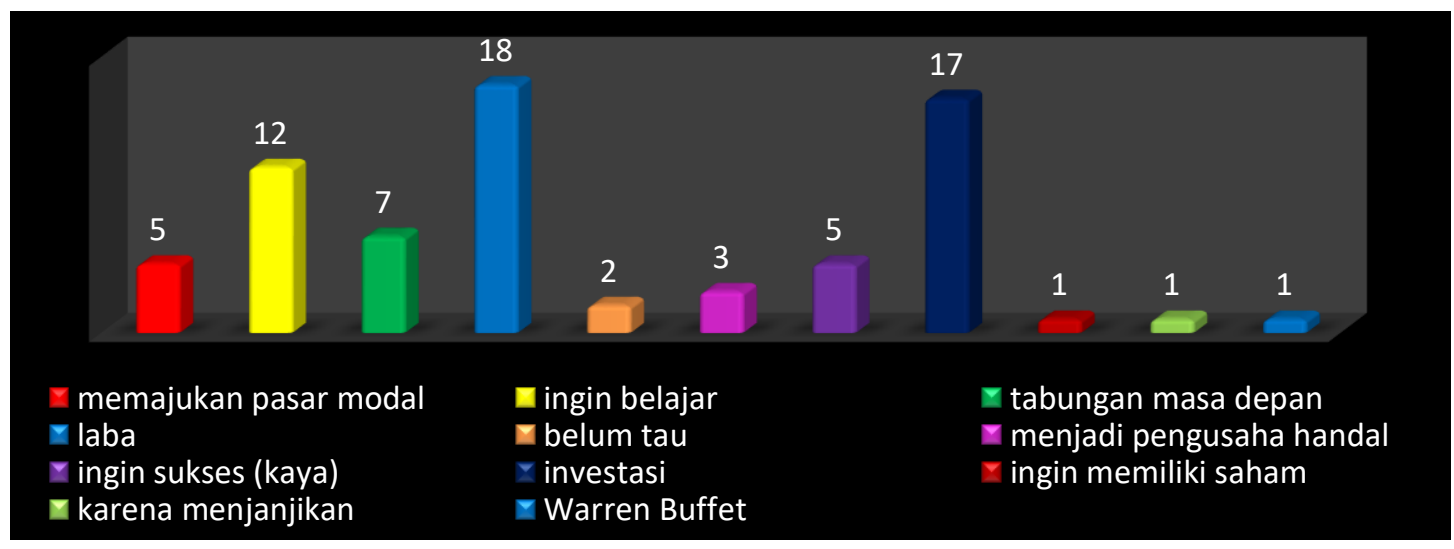

Gambar 6. Faktor yang Memotivasi Mahasiswa Berinvestasi di Pasar Modal Syariah

Sumber: Data primer yang diolah 
Berdasarkan data tersebut, ada beberapa faktor yang menjadikan responde berminta untuk investasi di pasar modal syariah. Faktor tersebut meliputi memajukan pasar modal di Indonesia, ingin lebih tahu (belajar), untuk tabungan masa depan (jangka panjang), ingin mendapatkan keuntungan (laba), karena belum tahu sehingga rasa ingin tahu muncul, ingin menjadi pengusaha (investor) sukses, ingin sukses (kaya), ingin berinvestasi, ingin memiliki saham, karena menjanjikan, dan warren buffet (karena terinspirasi tokoh). Faktor yang memotivasi paling tinggi adalah keinginan untuk mendapatkan laba, dikuti dengan keinginan untuk berinvestasi, dan kemudian keinginan untuk belajar. Keinginan untuk memperoleh keuntungan (gain), dibagi kedalam dua hal yaitu dividen dan capital gain. $71 \%$ responden termotivasi investasi di pasar modal syariah adalah agar mendapatkan deviden. Sementara itu, sisanya $29 \%$ termotivasi untuk mendapatkan capital gain. Dalam rangka berinvestasi para responden memilih berbagai instrumen yang paling diinginkan. Instrumen tersebut dipilih sebagai wadah untuk investasinya Adapun berbagai instrumen yang dipilih oleh para responden adalah sebagai berikut.

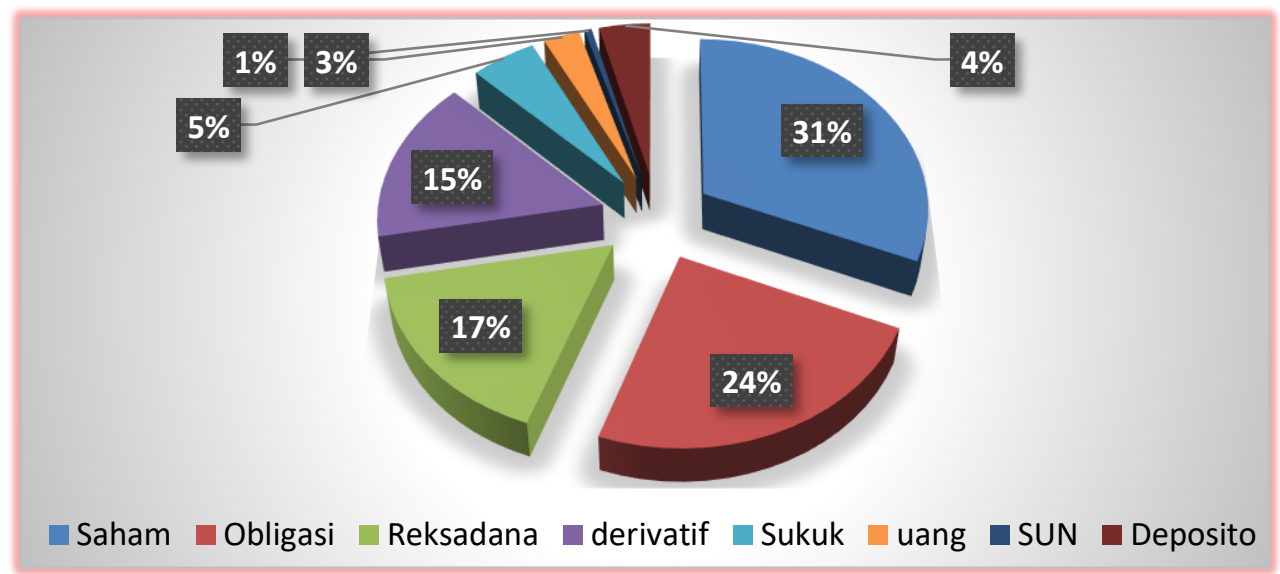

Gambar 7. Berbagai Pilihan Instrumen Investasi

Sumber: Data primer yang diolah

Data tersebut memuat beberapa pilihan, yang kemudian ada satu pilihan yang di isi selain yang ada pada pilihan oleh peneliti. Berdasarkan gambar di atas nampak jelas bahwa kebanyakan dari responden yaitu sebanyak $31 \%$ memilih saham sebagai pilihan untuk investasi. Pilihan berikutnya adalah obligasi, yaitu sebanyak $24 \%$, dan diikuti oleh reksadana sebesar $17 \%$, kemudian derivatif (right issue, waran, dan opsi) $15 \%$. Sukuk menempati pilihan berikutnya, yaitu $5 \%$ responden memilih sukuk sebagai wadah investasinya. Pilihan berikutnya adalah instrumen di luar pasar modal, yaitu uang (valas) $4 \%$, SUN adalah 1\%, dan deposito sebanyak 4\%. Namun demikian, sosialisasi dan edukasi yang sudah terlaksana masih belum signifikan dalam membangun minat investasi mahasiswa. Hal ini dikarenakan banyak faktor yang menghambat minat investasi tersebut. Berbagai faktor penghambat yang ditemukan dalam penelitian ini terdapat dalam gambar berikut ini

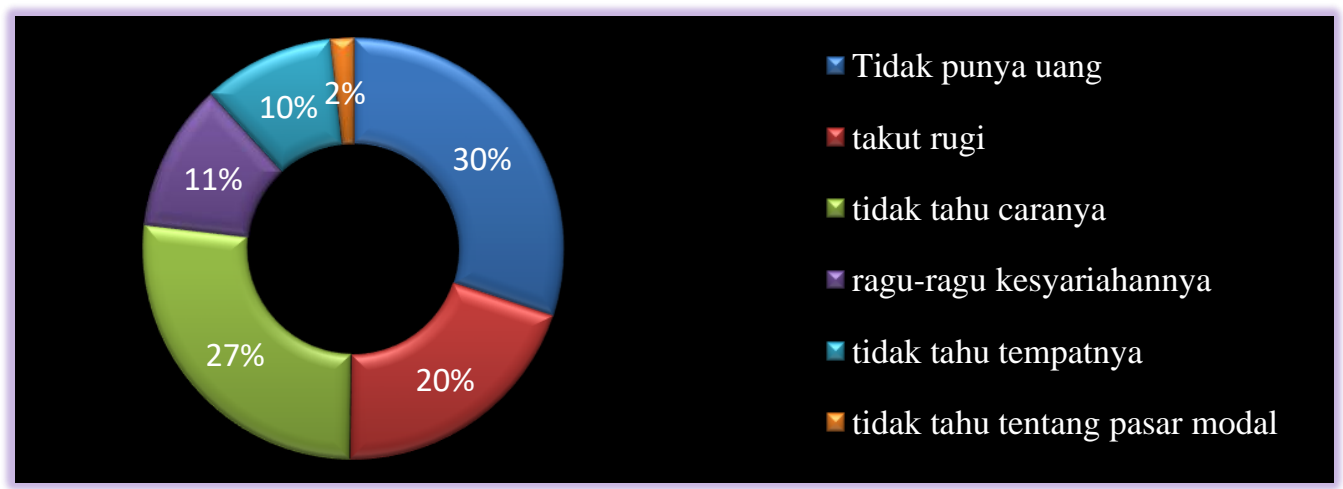

Gambar 8. Faktor-faktor yang Menghambat Minat Investasi di Pasar Modal Syariah Sumber: Data primer yang diolah 
Berdasarkan gambar di atas menunjukan bahwa faktor penghambat tertinggi adalah tidak memiliki modal (uang) untuk membuka rekening, dan juga untuk memulai investasi tersebut. Pada faktor yang pertama hampir dihadapi oleh 30 responden. Faktor penghambat kedua yaitu minimnya pengetahuan tentang pasar modal syariah, terutama caranya untuk berinvestasi. Pada faktor kedua tersebut juga menyumbang cukup tinggi yaitu sebesar $27 \%$ responden. Faktor penghambat berikutnya adalah takut akan risiko yang dihadapi atau takut mengalami kerugian, yaitu sebesar $20 \%$. Faktor penghambat minat investasi berikutnya adalah masih ragu-ragu dengan kesyariahannya. Pada faktor ini juga masih cukup tinggi, yaitu $11 \%$ dari responden. Faktor penghambat berikutnya adalah tidak tahu tempatnya (tempat untuk investasi), yaitu sebesar $10 \%$ dari responden. Faktor penghambat terakhir adalah tidak tahu sama sekali pasar modal syariah, yaitu sebesar $2 \%$ responden.

\section{Efektivitas Sosialisasi dan Edukasi dalam Membangun Minat Investasi di Pasar Modal Syariah}

Motivasi atau minat investasi para mahasiswa perlu dibangun sedemikian rupa agar dapat menjadi investor yang handal serta dapat mengajak orang lain, terutama masyarakat di sekitarnya atau di lingkungannya. Minat investasi pada dasarnya adalah tujuan sekunder, akan tetapi tujuan sebenarnya yang perlu dibangun pada diri mahasiswa adalah pengetahuan ataupun kompetensi pasar modal syariah yang mendalam. Hal ini dikarenakan mahasiswa merupakan agent of chance yang dapat mempengaruhi orang lain (masyarakat di sekitarnya). Jika mengacu pada salah satu faktor penghambat minimnya minat investasi di kalangan mahasiswa adalah karena ketidaktahuan yang kemudian menyebabkan hal-hal lain muncul seperti tidak tahu caranya dan tidak tahu tempatnya. Minimnya pengetahuan tentang pasar modal syariah juga berdampak pada keraguan akan kesyariahaannya, yang mana faktor ini juga ditemukan dengan angka yang tidak sedikit. Dengan demikian, faktor penghambat seperti tidak tahu caranya, tidak tahu tempatnya, dan ragu akan kesyariahannya adalah disebabkan karena faktor minimya pengetahuan. Jadi untuk solusi yang terbaik adalah dengan meningkatkan dan mengoptimalkan sosialisasi dan edukasi pasar modal syariah.

Faktor penghambat yang paling dominan adalah tidak adanya modal dan takut mengalami kerugian. Faktor permodalan memang tidak mudah untuk menyelesaikannya, akan tetapi dengan cara menurunkan modal untuk investasi oleh sekuritas menjadi solusi yang terbaik. Hal ini salah satu yang menjadi alasan bahwa mahalnya untuk memulai investasi di pasar modal syariah, terutama instrumeninstrumen seperti saham. Sementara faktor penghambat berikutnya masih berkaitan dengan pengetahuan mahasiswa itu sendiri, terlepas dari adanya risiko di pasar modal secara umum. Namun demikian, jika para mahasiswa dibekali dengan pengetahuan dan pengalaman yang cukup maka risiko kerugian dapat lebih diminalisir. Jadi dengan demikian, faktor penguatan pengetahuan menjadi faktor yang sangat fundamental dalam meningkatkan minat investasi mahasiswa.

Faktor pendukung juga dapat dimanfaatkan sebagai strategi untuk meningkatkan minat investasi mahasiswa. jika mendasarkan pada temuan di atas, faktor pendukung yang mendominasi adalah adanya keuntungan. Dengan mendasarkan pada faktor ini strategi yang perlu diterapkan adalah dengan cara memfasilitasi mahasiswa untuk melakukan simulasi ataupun trading langsung dengan modal yang ringan. Ketika para mahasiswa sudah mendapatkan keuntungan dan merasakannya, dengan sendirinya minat untuk investasi akan terbangun. Faktor pendukung lainnya sangat berkaitan erat dengan faktor keuntungan, seperti investasi, ingin sukses atau kaya, ingin memiliki saham dan wadah investasi yang menjanjikan. Sementara faktor lain seperti ingin tahu, ingin belajar, memajukan pasar modal di Indonesia, dan faktor pengalaman orang lain (tokoh) merupakan faktor yang mengarah pada edukasi. Dengan demikian, strategi yang terbaik adalah dengan mengoptimalkan sosialisasi dan edukasi yang lebih intensif.

Strategi mengoptimalkan sosialisasi dan edukasi adalah dengan cara memanfaatkan berbagai informan dan media sosial. Semakin beragamanya informan dan media sosial tentu akan semakin memperluas dan juga semakin merata informasi pasar modal syariah. Jika mengacu pada temuan di atas para informan yang terlibat antara lain teman, dosen, pengurus galeri investasi, seminar, kuliyah, media (cetak maupun elektronik), selebaran (iklan), guru SMA, buku, orang tua, dan internet. Berbagai informan tersebut memiliki intensitas yang berbeda serta memiliki peran/pengaruh yang beragam pula. Namun demikian meskipun beragam intensitas dan peran/pengaruhnya, pada dasarnya semua informan tetap penting dan juga tetap dibutuhkan.

Berdasarkan hasil di atas menunjukkan bahwa informan yang memiliki pengaruh besar adalah dosen melalui aktivitas perkuliahan. Dengan mendasarkan pada temuan ini, maka perlu adanya strategi 
untuk mengoptimalkan sosialisasi dan edukasi dengan mendasarkan pada informan ini. Salah satu strategi yang terbaik adalah dengan membangun sinergi antara pihak kampus dengan pihak sekuritas serta pihak PIPM. Sinergi tersebut dapat dilakukan melalui berbagai cara, antara lain melalui desain kurikulum mata kuliah terutama mata kuliah pasar modal syariah, melalui kerjasama dalam hal praktik lapangan (magang), dan juga kerjasama dalam hal kegiatan kampus (seminar, workshop, simulasi dan juga kompetisi pasar modal), serta membangun kerjasama dalam menyiapkan sumber daya manusia yang kompeten di bidang tersebut. Strategi desain kurikulum menjadi salah satu perhatian, karena strategi lainnya sudah mulai dilakukan. Strategi desain kurikulum yang terbaik adalah dengan cara melibatkan para praktisi untuk mengajar mata kuliah tersebut, sehingga mata kuliyah yang disampaikan akan lebih mendalam. Model perkuliahan juga perlu didesain yaitu tidak hanya disampaikan secara teoritis saja, akan tetapi perlu adanya simulasi atau bahkan jika memungkinkan adalah dengan cara mewajibkan setiap mahasiswa yang mengambil mata kuliyah tersebut untuk membuka rekening saham (modal ringan), sehingga selama perkuliahan berlangsung mahasiswa dapat langsung mempraktikan perkuliahannya.

Sementara itu, sosialisasi dan edukasi yang melalui media sosial yang meliputi facebook, BBM, line, blog, whatsap, instagram, kakaotalk, buku, twitter, internet (searching google), wechat, juga dapat dimanfaatkan sebagai strategi untuk mengoptimalkan sosialisasi dan edukasi. Media sosial tersebut memiliki intensitas yang beragam serta memiliki perana atau pengaruh yang beragam pula. Berdasarkan temuan facebook adalah media sosial yang mendominasi baik secara intensitas maupun peranannya. Dengan mendasarkan pada media sosial ini sosialisasi dan edukasi dapat dioptimalkan dengan memanfaatkan media facebook. Namun demikan, media lainnya juga masih diperlukan sebab akses setiap orang terhadap media berbeda-beda dan beragam. Jadi semua media masih diperlukan, hanya saja untuk media yang memiliki pengaruh kecil perlu adanya evaluasi dan perbaikan.

Informan maupun media, keduanya mempunyai peran masing-masing. Oleh karena itu, perlu diperluas dan dipotimalkan. Hal ini dikarenakan setiap orang mempunyai karakter yang berbeda-beda dalam menyerap informasi, ada yang lebih suka dengan mendengarkan, ada pula yang lebih suka dengan melihat (membaca atau menonton), adapula yang lebih suka dengan praktik langsung. Hal ini terbukti dengan beragamnya sebab yang kemudian menyebabkan mereka berminat untuk investasi, ada yang termotivasi melalui seminar, ada yang termotivasi melalui perkuliahan, ada yang termotivasi karena membaca buku, ada yang termotivasi karena media sosial, ada yang termotivasi karena media baik cetak maupun elektronik, ada yang termotivasi karena internet, ada yang termotivasi karena ikut organisasi, ada yang termotivasi karena datang ke galeri investasi, ada pula yang termotivasi karena datang ke PIPM, dan sebagainya. Dengan demikian semua aspek tersebut harus terus dikembangkan dan ditingkatkan serta lebih disinergikan agar sosialisasi dan edukasi lebih merata.

Jika mengacu pada data responden yang menjadi sampel dalam penelitian ini, yang mana responden merupakan mahasiswa yang tergabung dalam Fakultas Ekonomi dan Bisnis, baik di perguruan tinggi umum maupun perguruan tinggi Islam. Dengan mendasarkan pada sampel tersebut, seharusnya mahasiswa mempunyai pengetahuan lebih tentang pasar modal secara umum, dibandingkan dengan lingkungan fakultas non-ekonomi. Namun demikian, berdasarkan hasil yang diperoleh menunjukkan bahwa pengetahuan mahasiswa tentang pasar modal terutama lebih spesifik dengan label syariah masih belum signifikan terutama dalam membangun minat investasi mahasiswa. Maka hal ini bisa menjadi bahan kajian bahwa mahasiswa yang ada di lingkungan fakultas yang notabenya adalah bidangnya masih rendah pengetahuannya, apalagi mahasiswa yang ada non-ekonomi. Hal ini ditambah dengan adanya berbagai fasilitas untuk mengakses informasi tentang pasar modal syariah, misalnya galeri investasi. Di samping itu juga ditambah dengan adanya kelompok atau organisasi mahasiswa yang concern mengkaji pasar modal. Namun demikian, dengan berbagai fasilitas tersebut hasil menunjukkan bahwa masih belum signifikan. Dengan demikian perlu adanya langkah strategis untuk meningkatkan dan mengoptimalkan sosialisasi dan edukasi terutama di lingkungan fakultas ekonomi.

\section{SIMPULAN}

Berdasarkan hasil dan pembahasan, maka dapat disimpulkan sebagai berikut:

Sosialisasi dan edukasi kepada para mahasiswa melibatkan berbagai informan yang meliputi teman, dosen, pengurus galeri investasi, seminar, kuliyah, media (cetak maupun elektronik), selebaran, guru SMA, buku, orang tua, dan internet. Sosialisasi dan edukasi juga melibatkan berbagai media sosial 
yang meliputi facebook, BBM, line, blog, whatsap, instagram, kakaotalk, buku, twitter, internet (searching), dan wechat.

Peranan masing-masing informan dan media beragam, baik dari sisi intensitas maupun pengaruhnya (peranan) terhadap minat investasi mahasiswa. Hasil menunjukkan bahwa informan yang paling berpengaruh adalah aktivitas perkuliahan yang kemudian melibatkan dosen. Sementara itu, media sosial yang memiliki kontribusi paling besar adalah media facebook.

Hasil juga menunjukkan bahwa ada beberapa faktor yang mendukung dan menghambat minat investasi mahasiswa. Faktor pendukung minat investasi mahasiswa antara lain memajukan pasar modal di Indonesia, ingin lebih tahu (belajar), untuk tabungan masa depan (jangka panjang), ingin mendapatkan keuntungan (laba), karena belum tahu sehingga rasa ingin tahu muncul, ingin menjadi pengusaha (investor) sukses, ingin sukses (kaya), ingin berinvestasi, ingin memiliki saham, karena menjanjikan, dan Warren Buffet (karena terinspirasi tokoh). Sementara itu faktor pengahambat minat investasi mahasiswa meliputi tidak adanya modal (uang), takut akan kerugian, kurangnya pengetahuan baik caranya mapun tempatnya, dan ragu-ragu kesyariahannya.

Perlu adanya strategi untuk mengoptimalkan peranan informan dan media agar sosialisasi dan edukasi semakin luas dan merata. Untuk mengoptimalkan peranan tersebut, maka untuk informan dan media sosial yang memiliki pengaruh besar untuk terus ditingkatkan baik secara intensitas maupun sinerginya, sedangkan yang memiliki pengaruh kecil perlu dilakukan evaluasi dan pembenahan. Jika mengacu pada faktor penghambat, maka perlu mencari solusi untuk meminimalisir faktor tersebut. Sementara itu, jika mengacu pada faktor pendukung dan penghambat maka strategi yang terbaik adalah dengan cara mensinergikan pihak kampus, PIPM, dan perusahaan sekuritas terutama dalam mendesain kurikulum mata kuliyah pasar modal syariah. Desainnya adalah dengan cara memberikan kesempatan kepada para praktisi untuk mengajar, di samping itu juga model perkuliahannya tidak hanya bersifat teorities akan tetapi juga praktis baik simulasi maupun praktik langsung menjadi investor.

\section{DAFTAR PUSTAKA}

Bungin, Burhan, 2013, Metodologi Penelitian Sosial dan Ekonomi; Format-format Kuantitatif dan Kualitatif untuk Studi Sosiologi, Kebijakan Publik, Komunikasi, Manajemen, dan Pemasaran, Jakarta: Kencana.

Direktorat Pasar Modal Syariah Otoritas Jasa Keuangan, 2015, Roadmap Pasar Modal Syariah 20152019; Membangun Sinergi untuk Pasar Modal Syariah yang Tumbuh Stabil, dan Berkelanjutan.

Gunawan. (2011). Pengaruh Analisis Fundamental Terhadap Harga Saham (Studi Empiri Terhadap Saham-Saham Syariah Di Jakarta Islamic Indeks). Jurnal Wira Ekonomi Mikroskil, 1(April), 4758 .

Idrus, Muhammad, 2009, Metode Penelitian Ilmu Sosial Pendekatan Kualitatif dan Kuantitatif, Yogyakarta: Erlangga.

Khotimah, H., Warsini, S., \& Nuraeni, Y. (2016). Pengaruh Sosialisasi dan Pengetahuan Terhadap Minat Investor Pada Efek Syariah di Pasar Modal (Survei Pada Nasabah PT Danareksa Sekuritas Cabang FE-UI Depok). Account, 423-433. Retrieved from http://akuntansi.pnj.ac.id/upload/artikel/files/SabarWaarsiniJuni2016.pdf

Peristiwo, H. (2016). Analisis Minat Investor Di Kota Serang Terhadap Investasi Syariah Pada Pasar Modal Syariah. Ekonomi Keuangan Dan Bisnis Islam, 7(1), 37-52.

Roadmap Pasar Modal Indonesia 2015-2019 (Online). (http://www.ojk.go.id, diakses 10 Maret 2016)

Supriadi, F., \& Hariyanto, D. (2017). FAKTOR PERTIMBANGAN MASYARAKAT MEMILIH DAFTAR EFEK SYARIAH. Jurnal Manajemen MOTIVASI, 13(No. 1), 802-806.

Tim Studi Analisa Efektifitas Penyebaran Informasi Dalam Rangka Sosialisasi Pasar Modal. 2006. Analisa Efektifitas Penyebaran Informasi Dalam Rangka Sosialisasi Pasar Modal. Jakarta

Yanti, M., Ubud, S., Made, S., \& Djumahir. (2012). Determinan Price Earning Ratio dan Stock Return (Studi pada Saham-saham Syariah di Bursa Efek Indonesia). Jurnal Aplikasi Manajemen, 10(66), 273-290. 